\title{
Bmf is a possible mediator in histone deacetylase inhibitors FK228 and CBHA-induced apoptosis
}

\author{
Y Zhang ${ }^{1,2}$, M Adachi $^{* \cdot 1,2}$, Kawamura $^{1,2}$ and $\mathrm{K}$ Imai $^{2}$ \\ 1 Division of Molecular Oncology and Molecular Diagnosis, Graduate School of \\ Medicine, Sapporo Medical University School of Medicine, Sapporo, Japan; \\ 2 First Department of Internal Medicine, Sapporo Medical University School of \\ Medicine, Sapporo, Japan \\ * Corresponding author: M Adachi, First Department of Internal Medicine, \\ Sapporo Medical University School of Medicine, S-1, W-16, Chuo-ku, Sapporo \\ 060-8543, Japan. Tel: + 8111611 2111; Fax: + 8111611 2282; \\ E-mail: adachi@sapmed.ac.jp
}

Received 10.1.05; revised 20.4.05; accepted 22.4.05; published online 10.6.05 Edited by A Strasser

\begin{abstract}
Histone deacetylase (HDAC) inhibitors modify transcription of selected genes and eventually induce apoptosis. However, molecular mechanisms for their proapoptotic activity remain unclear. We here demonstrate that HDAC inhibitors FK228 and $\mathrm{CBHA}$ preferentially upregulated the $\mathrm{BH} 3$-only protein Bmf in a broad range of cancer cells. In contrast, HDAC1 overexpression distinctly reduced Bmf expression. FK228 induced histones $\mathrm{H} 3$ and $\mathrm{H} 4$ acetylation at Bmf promoter region, but not at its $3^{\prime}$ region, suggesting that histone hyperacetylation causes Bmf transcriptional activation. Knockdown of Bmf transcripts rescued cells from FK228 or CBHA-induced cell death, disruption of mitochondrial membrane potential $(\Delta \Psi \mathrm{m})$ and DNA fragmentation. Taken together, FK228 and CBHA activate Bmf transcription by histone hyperacetylation at its promoter region, and inhibition of this action decreased their proapoptotic activity, thereby highlighting a central role of Bmf in HDAC inhibitor-mediated apoptosis.

Cell Death and Differentiation (2006) 13, 129-140.

doi:10.1038/sj.cdd.4401686; published online 10 June 2005
\end{abstract}

Keywords: acetylation; histone deacetylase inhibitor; Bmf; apoptosis; transcription; apoptosis

Abbreviations: HDAC, histone deacetylase; $\triangle \Psi \mathrm{m}$, mitochondrial membrane potential; HAT, histone acetyltransferase; $\mathrm{CBHA}$, m-carboxycinnamic acid bis-hydroxamide; DLC, dynein light chain; ChIP, chromatin immunoprecipitation

\section{Introduction}

Acetylation and deacetylation can modify a variety of target molecules including signaling molecules and histones, and regulate key cellular processes. ${ }^{1}$ Histone deacetylase (HDAC) inhibitors can induce hyperacetylation of histones through a relative increase of histone acetyltransferase (HAT) activity resulting from inactivation of HDAC. They increase transcription activity by altering chromatin structure, but interestingly they activate transcription of selected genes and cause terminal differentiation, cell-cycle arrest or apoptosis in a variety of cancer cells. ${ }^{2-6}$ Since the antiproliferative and proapoptotic activity is somehow restricted to transformed cells, HDAC inhibitors are promising new class of anticancer agents against a broad range of hematologic and solid tumors. ${ }^{7}$ So far Phase I clinical trials with an HDAC inhibitor the depsipeptide FK228 are encouraging and Phase II trials have been initiated in cutaneous T-cell lymphoma, peripheral T-cell lymphoma, and recurrent or metastatic squamous cell carcinoma (SCC) of the head and neck. ${ }^{8-10}$ Another HDAC inhibitor m-carboxycinnamic acid bis-hydroxamide (CBHA) is the hybrid-polar compound, and exhibits strong anticancer activity. ${ }^{11-13}$ As they induce histone hyperacetylation and activate some transcription factors, but do not affect DNA directly, they differ strikingly from most other anticancer agents which interfere with DNA synthesis or cell division.

Although HDAC inhibitors are promising anticancer drugs, molecular mechanisms of cell death after HDAC inhibitor treatment remain poorly understood. Hyperacetylation of histones and/or nonhistone proteins and subsequent gene transcription may be primarily involved in the mechanism(s). Among the HDAC inhibitor-mediated inducible genes, cyclindependent kinase inhibitor $\mathrm{p} 21^{\mathrm{WAF} 1}$ and gelsolin are proposed to be important for their biological effects. Induction of p21 WAF1 is tightly associated with HDAC inhibitor antiproliferative action while upregulation of gelsolin is a potential mechanism for inhibition of tumor progression. ${ }^{14-17}$ More recently, TRAIL receptor was found to be upregulated by several HDAC inhibitors, explaining why cancer cells are sensitized to TRAIL. ${ }^{18}$ In contrast, HDAC inhibitors somehow increase degradation of several apoptosis-related proteins, such as p53, bcr-abl and cellular FADD-like interleukin 1- $\beta$ converting enzyme (FLICE)-inhibitory protein FLIP. ${ }^{19-21}$ However, it is unlikely that these molecules play pivotal roles in the broad spectrum of HDAC inhibitor-induced apoptosis. A recent report shows that HDAC inhibitors increase acetylation of Ku70 and abolish its ability to suppress Bax-mediated apoptosis. ${ }^{22}$ This suggests that the mitochondria-mediated death signals may be crucial for HADC inhibitor-mediated apoptosis. Based on this idea, we have been attempting to identify novel HDAC inhibitor-inducible proapoptotic genes. Previously, we reported that HDAC inhibitors CBHA, FK228 and MS-275 increase a proapoptotic $\mathrm{BH} 3-$ only Bim in gastrointestinal adenocarcinoma MKN45 and DLD-1 cells. ${ }^{23}$ This strongly suggests that Bim is one of the target genes of HDAC inhibitors and tightly links to the mitochondria-mediated apoptosis. Extending this study, we found that these HDAC inhibitors did not always increase Bim mRNA in other cancer cell types. Since HDAC inhibitors can strongly induce apoptosis in a wide range of cancer cells, it is unlikely that $\mathrm{Bim}$ is the sole target molecule, and additional mechanism(s) are probably involved in the process. We demonstrate here 
that $\mathrm{CBHA}$ and FK228 strongly induced expression of another $\mathrm{BH} 3-$ only protein, Bmf, in a broader range of cancer cell types than does Bim. We also show that the Bmf induction was caused by histone hyperacetylation and siRNA-mediated knockdown of Bmf induction strongly reduced HDAC inhibitormediated apoptosis. Since JNK phosphorylates and activates Bmf by sequestering it from dynein light chain 2 (DLC2), ${ }^{24}$ it may also be involved in the apoptotic process, but our results represent transcription activation as an additional mechanism for Bmf activation, and explain, at least in part, how HDAC inhibitors induce apoptosis.

\section{Results}

\section{FK228 and CBHA induce Bmf expression}

We recently reported that three different HDAC inhibitors FK228, CBHA and MS-275 clearly increase the BH3-only protein Bim expression in two adenocarcinoma cells, and enhance their radiosensitivity. ${ }^{23}$ Since these HDAC inhibitors can induce apoptosis in a wide range of cancer cells, elevated Bim expression might be generally observed in the process of apoptosis. In fact, FK228 or CBHA treatment clearly elevated Bim mRNA in several adenocarcinoma cells including DLD-1, BM314, COLO201 and A549, but the treatment did not apparently increase Bim mRNA expression in other cancer cells (Figure 1). We therefore, monitored mRNA expression levels of a variety of apoptosis-related molecules including the Bim-related BH3-only protein Bmf mRNA. Importantly, Bmf transcripts, although induced differently in different cells, were more strongly induced by FK228, CBHA or both in all cell lines we examined (Figure 1). We observed that Bmf, but not Bim, was strongly induced in the oral and esophageal squamous carcinoma cells, SAS, HSC-2 and T Tn, which suggests to us that Bmf induction may be of primary importance for FK228 and $\mathrm{CBHA}$-induced apoptosis, especially in these squamous carcinoma cells.

To determine whether Bmf induction is crucial for FK228mediated cell death in SAS cells, we first monitored acetylation of histone $\mathrm{H} 4$ after FK228 treatment. The kinetics of histone $\mathrm{H} 4$ acetylation revealed that hyperacetylation was detectable at $1 \mathrm{~h}$ after $5 \mathrm{nM} \mathrm{FK} 228$ treatment, and $5 \mathrm{nM}$ but not $1 \mathrm{nM}$, strongly increased it at $6 \mathrm{~h}$ (Figure 2a). We then evaluated the anticancer activity of FK228 in SAS cells. Treatment with $5 \mathrm{nM}$ FK228, but not $1 \mathrm{nM}$, strongly induced death at $48 \mathrm{~h}$, and at higher doses extensively enhanced cell death (Figure $2 \mathrm{~b}$ ). Treatment with $10 \mathrm{nM}$ FK228 caused a distinct loss of mitochondrial membrane potential $(\Delta \Psi \mathrm{m})$ at $24 \mathrm{~h}$ (Figure 2c). The kinetics of Bmf mRNA induction revealed that $5 \mathrm{nM}$ FK228 treatment began to increase Bmf mRNA at $6 \mathrm{~h}$ and thereafter it gradually increased (Figure $2 \mathrm{~d}$ ), indicating that the induction occurred prior to the loss of $\Delta \Psi \mathrm{m}$. We next monitored the gene expression of proapoptotic Bcl-2 family members, Bmf, BAX, BAD, BID and Bim $24 \mathrm{~h}$ after FK228 treatment. More than $5 \mathrm{nM} F K 228$, but not $1 \mathrm{nM}$, clearly increased Bmf mRNA expression, while it barely affected expression of the other $\mathrm{Bcl}-2$ family members (Figure $2 \mathrm{~d}$ and e). Treatment with $20 \mathrm{nM}$ FK228 elevated Bmf transcripts approximately 20-fold as assessed by real-time PCR (Figure 2f). Thus, FK228 selectively induces Bmf among the Bcl-2 family members.

To evaluate whether the expressed Bmf is functional in SAS cells and able to induce apoptosis, we isolated a Bmf fulllength mRNA clone from SAS total mRNAs and subcloned its

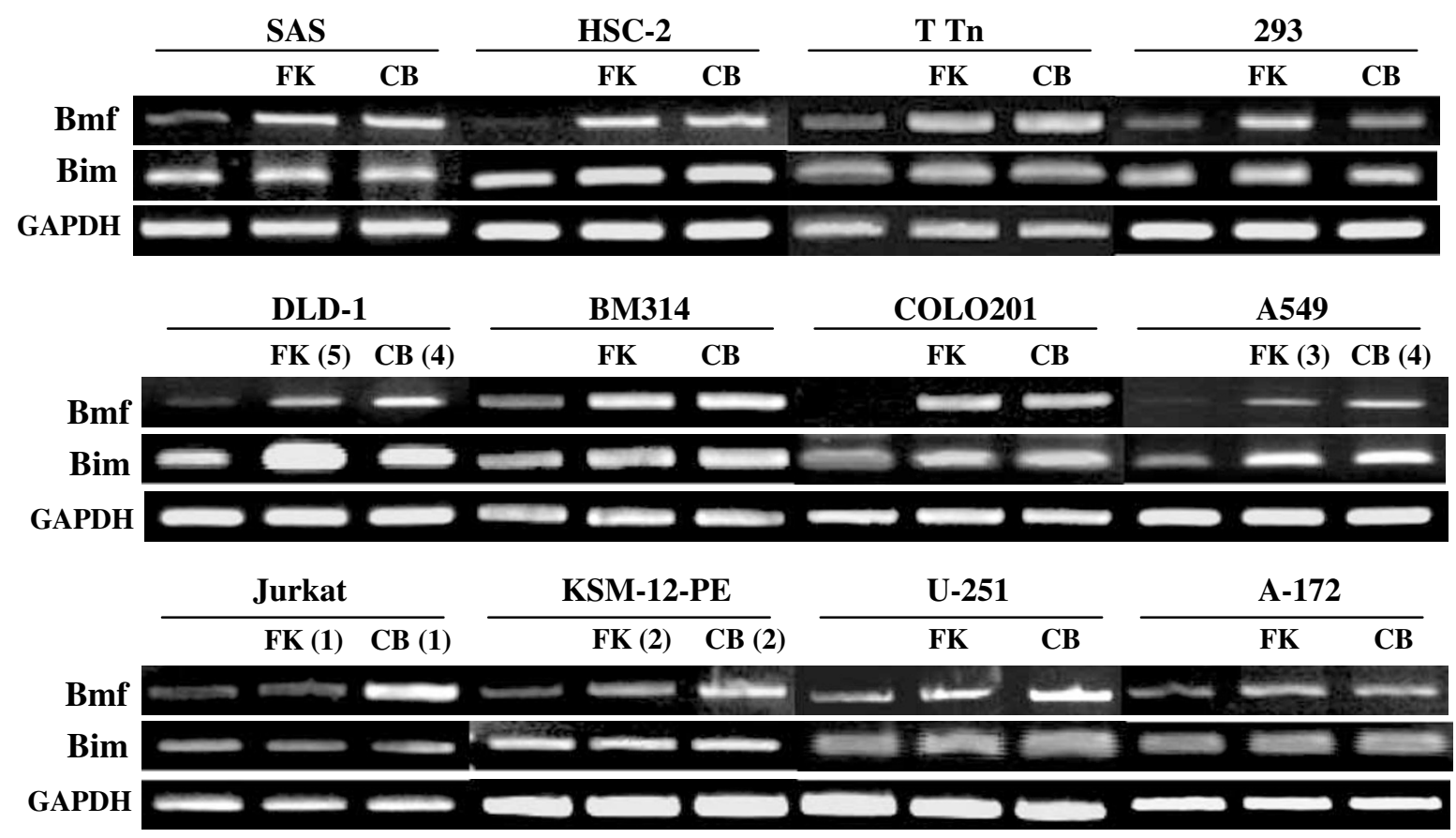

Figure 1 Induction of Bmf and Bim mRNA in FK228 or CBHA-treated cells. Total RNAs were harvested from cells treated with $10 \mathrm{nM}$ FK228 (FK) or $8 \mu \mathrm{M} \mathrm{CBHA} \mathrm{(CB)}$ (unless indicated) for $12 \mathrm{~h}$ (COLO201, A549, Jurkat and KSM-12-PE) or $24 \mathrm{~h}$ (others). Primers specific to the GAPDH mRNA were used in RT-PCR to ensure that the RNAs were correctly quantitated 
a

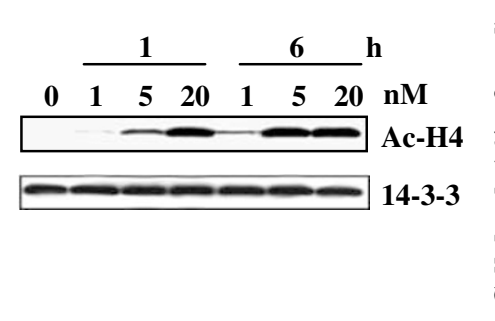

b

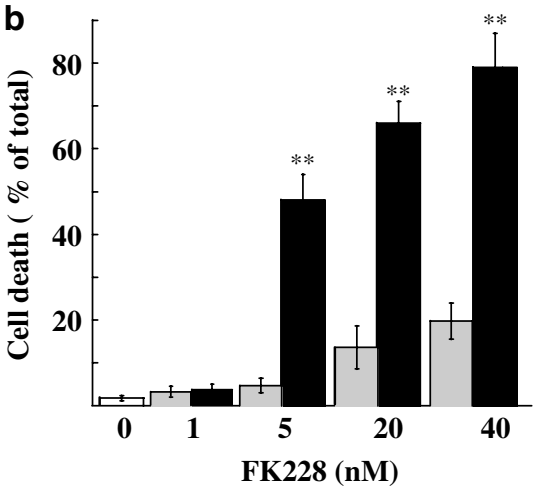

C

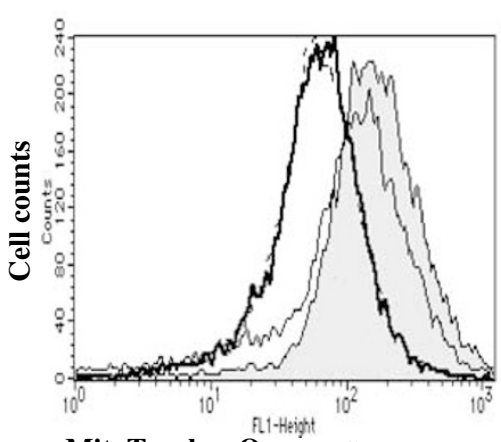

MitoTracker Orange CM- $\mathrm{H}_{2}$ TMRos

d

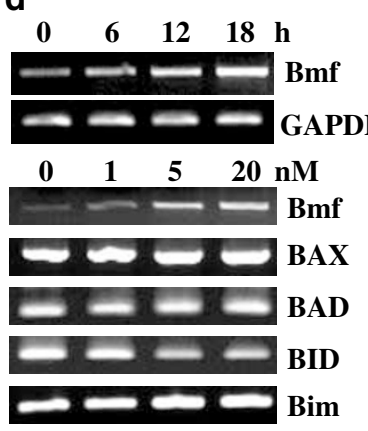

e

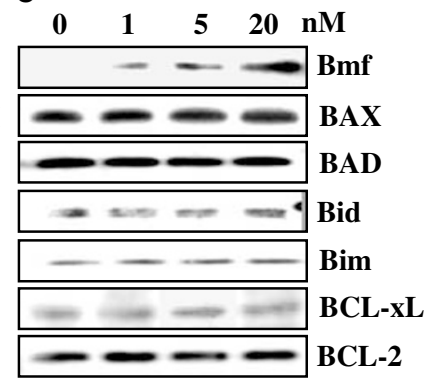

f

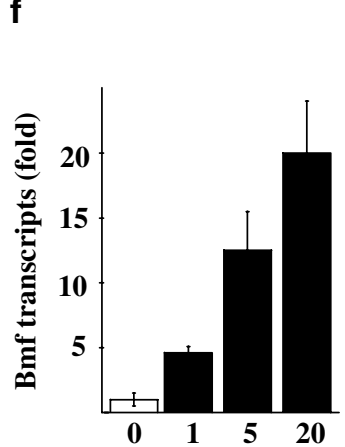

g Mock Bmf

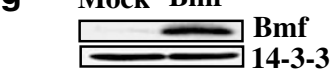

Figure 2 Cell death in FK228-treated SAS cells. (a) Histone hyperacetylation. Cells were incubated with FK228 at indicated doses (nM) for 1 or $6 \mathrm{~h}$, and acetylation of histone $\mathrm{H} 4(\mathrm{Ac}-\mathrm{H} 4)$ was evaluated by Western blots. 14-3-3 protein levels show the same amount of protein loaded in each lane. (b) Trypan blue exclusion assay. Cell death at $24 \mathrm{~h}$ (gray) or $48 \mathrm{~h}$ (closed bars) after treatment with the indicated concentrations of FK228. (c) Disruption of $\Delta \Psi \mathrm{m}$. Cells were treated with $5 \mathrm{nM}$ (thin), $10 \mathrm{nM}$ (thick line) or without (gray shadow) FK228 for $24 \mathrm{~h}$, then loaded with MitoTracker Orange CM- $\mathrm{H}_{2}$ TMRos, which becomes actively fluorescent after mitochondrial oxidation and intracellular fluorescence was detected. (d) Time course and dose-response of Bmf mRNA induction. Total RNAs were prepared from cells cultured with $5 \mathrm{nM} \mathrm{FK} 228$ for the indicated hours (upper panels) or with the indicated doses of FK228 for $12 \mathrm{~h}$ (lower panels). RT-PCR was performed by the indicated primers. (e) Expression of apoptosis-related proteins. Western blots of indicated proteins in cells treated as (d) for $24 \mathrm{~h}$. (f) Quantitative real-time PCR. In total RNAs described in (e), Bmf and $\beta$-actin mRNA levels were determined by real-time PCR and data were normalized to $\beta$-actin levels. (g) Cell death in Bmf-overexpresing transfectants. Cells were transfected with GFP-Bmf (1.6 $\mu \mathrm{g} / 4 \mathrm{~cm}^{2}$ ) or its vehicle pEGFPC2 (Mock). Overexpression of Bmf is shown (upper panel). At $24 \mathrm{~h}$ after transfection, cell death was evaluated by trypan blue exclusion assay. In $\mathbf{b}, \mathbf{f}$ and $\mathbf{g}$, columns display the mean \pm S.D. of data from three separate experiments. ${ }^{* \star} P<0.01$

cDNA fragment into a pEGFP expression vector. As expected, overexpression of Bmf induced extensive cell death (Figure 2g), confirming that the increased Bmf is functional and its overexpression causes extensive cell death in SAS cells.

\section{Bmf mRNA knockdown decreases FK228- mediated apoptosis}

To evaluate biological significance of the Bmf induction in FK228-mediated apoptosis, we used siRNA-mediated knockdown of Bmf expression in SAS cells. Double-stranded siRNA oligonucleotides directed toward Bmf were transfected into SAS cells, significantly reducing Bmf mRNA induction (Figure 3a). Real-time PCR quantitative assay revealed that FK228 increased Bmf mRNA levels five-fold, which was almost completely inhibited by transfection of Bmf siRNA, while random siRNA rather slightly increased them (Figure 3b). Thus, Bmf siRNA transfection can strongly knockdown Bmf transcripts, and allows us to evaluate the biological roles of Bmf induction in FK228-induced apoptosis. Knocking down Bmf protein levels (Figure 3c) and treating the cells with FK228 significantly reduced FK228-induced apoptotic death, DNA fragmentation, annexin $\mathrm{V}$ expression and loss of $\Delta \Psi \mathrm{m}$ (Figure $3 \mathrm{~d}-\mathrm{g}$ ). These data strongly suggest that FK228-induced Bmf expression may be crucial for FK228mediated apoptosis.

\section{Another HDAC inhibitor CBHA, but not cisplatin, increased Bmf expression and induced death}

HDAC inhibitors modify expression of a variety of genes mostly through histone hyperacetylation, but they also affect intracellular signaling pathways as described previously. ${ }^{25}$ To investigate whether our findings are tightly linked to histone hyperacetylation, we evaluated the anticancer effects of another HDAC inhibitor CBHA in SAS cells. CBHA treatment clearly induced death in a dose-dependent manner (Figure 4a). More than $2 \mu \mathrm{M}$ CBHA clearly increased Bmf transcripts (Figure 4b) and $4 \mu \mathrm{M}$ CBHA elevated Bmf transcripts approximately 12 -fold as assessed by real-time PCR (Figure 4c). Thus, like FK228, CBHA also increased Bmf mRNA and induced death in SAS cells. In contrast, a common anticancer agent cisplatin did not appreciably induce Bmf 
a
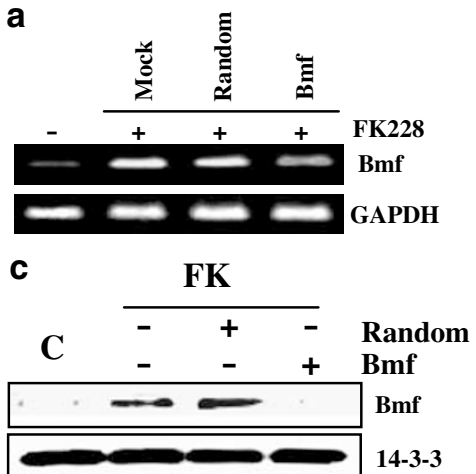

d

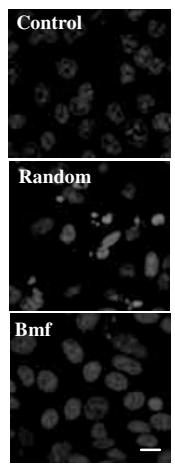

b

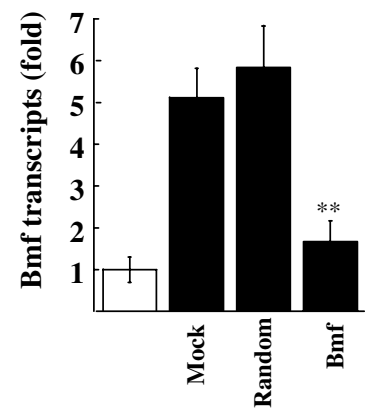

e

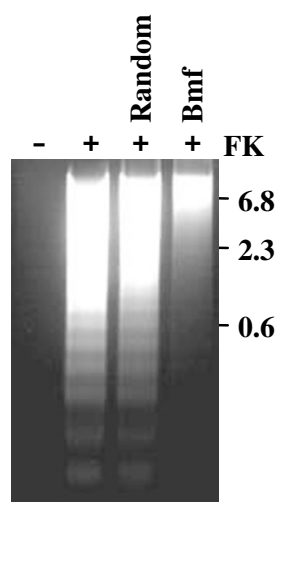

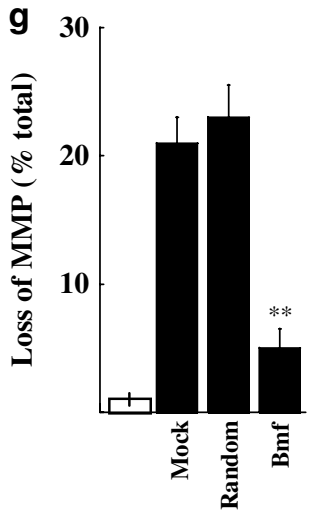

MitoTracker Orange CM-H,TMRos
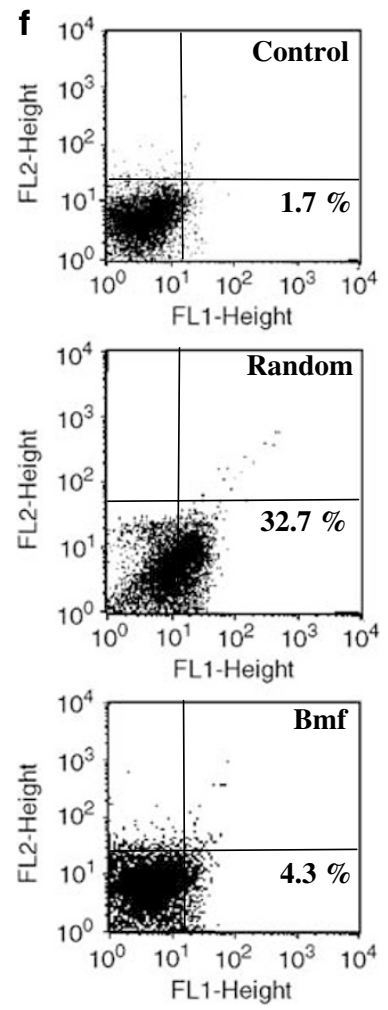

Figure 3 Knockdown of Bmf transcripts reduced FK228-induced apoptosis. (a) RT-PCR. After incubation for $12 \mathrm{~h}$ with $10 \mathrm{nM}$ FK228 followed by siRandom (Random) or siBmf (Bmf) transfection, Bmf mRNA was evaluated by RT-PCR. GAPDH mRNA is shown to ensure that the RNAs were correctly quantitated. (b) Quantitative realtime PCR. In total RNAs described in (a), Bmf (normalized to $\beta$-actin) mRNA levels were determined by real-time PCR. (c) Western blot analysis of Bmf. Cells were incubated with or without $10 \mathrm{nM}$ FK228 for $24 \mathrm{~h}$ after transfection with siRandom or siBmf. The blot was probed with the anti-Bmf or anti-14-3-3 antibody. (d) DAPI staining assay. Cells were transfected with siRNA duplexes (siRandom or siBmf). Apoptotic cell death was evaluated by DAPI staining assay at $36 \mathrm{~h}$ after $10 \mathrm{nM}$ FK228 treatment (closed bars). Representative data are shown in the left panel. (e) DNA fragmentation. Cells were transfected with the indicated siRNA duplexes and lowmolecular weight DNA was prepared $30 \mathrm{~h}$ after $10 \mathrm{nM}$ FK228 treatment $(+)$. Molecular weight markers $(\mathrm{kb})$ are shown to the right. (f) Annexin V staining. Cells were transfected with the indicated siRNA duplexs and numbers indicate \% apoptotic cells (annexin V + $/ \mathrm{PI}-$ ) $24 \mathrm{~h}$ after $10 \mathrm{nM} \mathrm{FK228} \mathrm{treatment.} \mathrm{(g)} \mathrm{Disruption} \mathrm{of} \Delta \Psi \mathrm{m}$. Cells were transfected with the indicated siRNA duplexes, treated with (closed) or without (open bar) $10 \mathrm{nM}$ FK228 for $24 \mathrm{~h}$, loaded with MitoTracker Orange CM$\mathrm{H}_{2}$ TMRos and then intracellular fluorescence was detected. Columns $(\mathbf{b}, \mathbf{d}, \mathbf{g})$ display the mean + S.D. of data from three separate experiments. ${ }^{*} P<0.01$ compared with siRandom transfection

mRNA (Figure 4d), implying a specific role of Bmf in HDAC inhibitor-mediated signals. To evaluate the biological significance of Bmf induction in $\mathrm{CBHA}$ or cisplatin-treated cells, both reagents were added to the Bmf siRNA or random siRNA-transfected cells. Knockdown of Bmf transcripts clearly inhibited FK228- or CBHA-induced death, but did not affect cisplatin-induced death and annexin $\mathrm{V}$ expression significantly (Figure $4 \mathrm{e}$ and f). Furthermore, knockdown of another BH3-only protein Bim expression barely inhibited FK228-induced death (Figure 5a-c). These data suggest that $\mathrm{Bmf}$ transcripts are specifically induced and this event may be crucial in HDAC inhibitor-induced apoptosis.

We next explored whether these HDAC inhibitors directly induce Bmf expression. Coincubation with cycloheximide (CHX) strongly inhibited the FK228-mediated induction of Bmf proteins, but $\mathrm{CHX}$ did not affect FK228 or CBHAinduced Bmf transcripts (Figure $5 \mathrm{~d}$ ). These data strongly suggest that the Bmf mRNA induction does not require protein synthesis.

\section{Bmf knockdown prolonged survival in FK228 or CBHA treatment}

To address the question whether Bmf knockdown can maintain cell viability in longer treatment. To maintain the Bmf expression downregulated, SAS cells were transfected twice with the indicated siRNAs. Colony assay clearly revealed that Bmf knockdown significantly increased survival fraction (Figure $5 e$ ), strongly suggesting a crucial role of $\mathrm{Bmf}$ in the HDAC inhibitor-mediated death.

\section{FK228 and CBHA induced cell death in HSC-2 cells}

Having demonstrated that two independent HDAC inhibitors strongly induced Bmf expression and that knocking down of Bmf expression strongly inhibited their proapoptotic effects, suggests that Bmf induction is crucial for HDAC inhibitorinduced death in SAS cells. We next investigated whether FK228 and CBHA have similar effects in other cells. In human oral SCC HSC-2 cells, 4 nM FK228 or $16 \mu \mathrm{M}$ CBHA was 

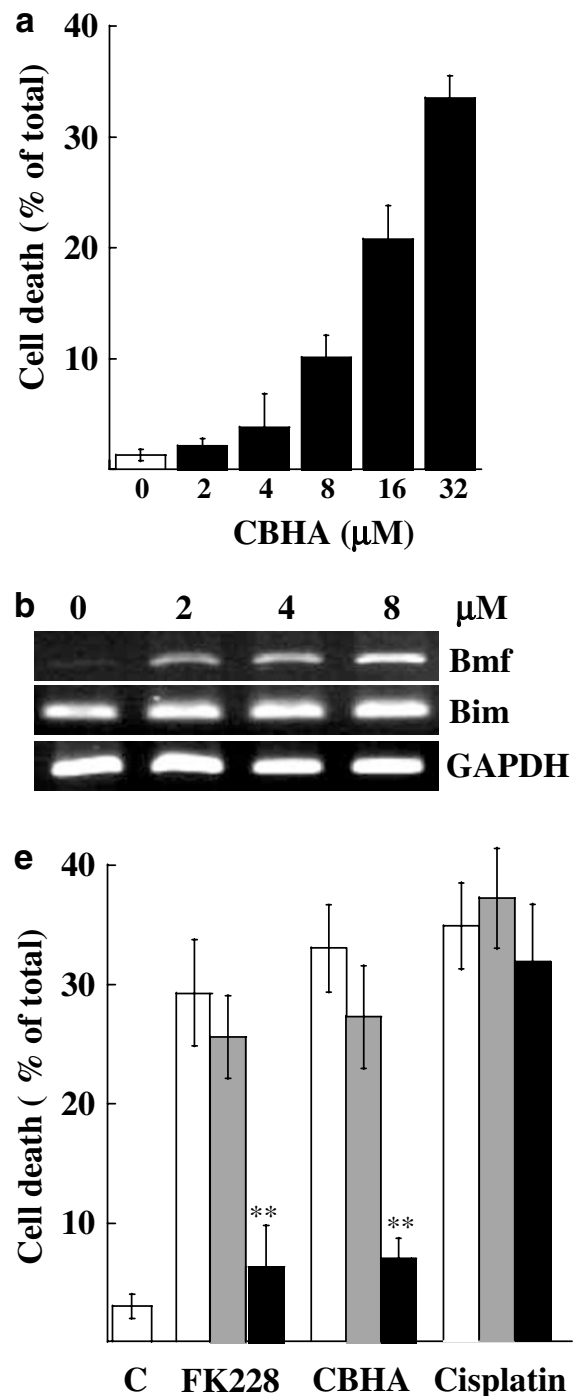
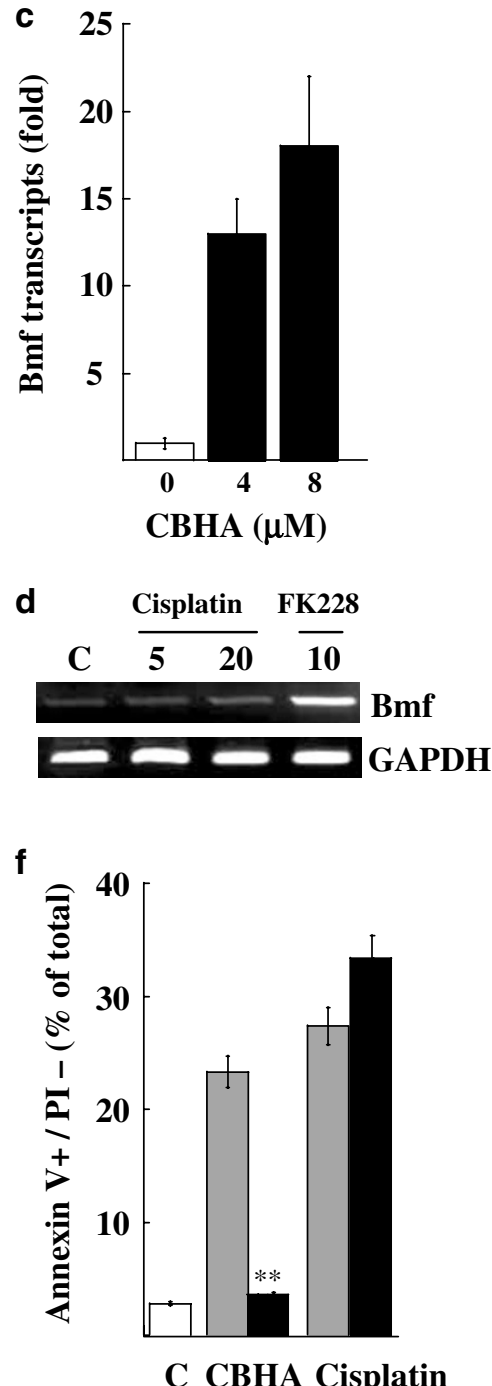

Figure 4 Bmf mRNA induction in CBHA-induced death. (a) Trypan blue exclusion assay. Cell death at $24 \mathrm{~h}$ after treatment with the indicated concentrations of CBHA. (b) RT-PCR. Bmf or Bim mRNAs expression at $12 \mathrm{~h}$ after incubation with the indicated concentrations of CBHA $(\mu \mathrm{M})$. (c) Quantitative real-time PCR. In total RNAs described in (b), Bmf (normalized to $\beta$-actin) mRNA levels were determined by real-time PCR. (d) RT-PCR. Bmf mRNA expression at $12 \mathrm{~h}$ after incubation with the indicated concentrations of Cisplatin $(\mu \mathrm{M})$ or FK228 (nM). (e) Trypan blue exclusion assay. Cells were cultured for $12 \mathrm{~h}$ after transfection with the siRNA duplexes (mock, open; siRandom, gray; siBmf, closed bars), further incubated with the indicated treatment (10 nM FK228, $8 \mu \mathrm{M} \mathrm{CBHA}$ or $20 \mu \mathrm{M}$ cisplatin) for $36 \mathrm{~h}$ and cell death was evaluated. (f) Annexin V expression. Cells were cultured for $12 \mathrm{~h}$ after transfection with the siRNA duplexes (siRandom, gray; siBmf, closed), further cultured for $24 \mathrm{~h}$ and annexin $V$ expression was evaluated. ${ }^{\star \star} P<0.01$ compared with siRandom transfected cells (e and $\left.\mathbf{f}\right)$. Columns $(\mathbf{a}, \mathbf{c}, \mathbf{e}, \mathbf{f})$ display the mean \pm S.D. of data from three separate experiments

sufficient to induce distinct histone acetylation at $1 \mathrm{~h}$ after treatment (data not shown), and specifically increased Bmf mRNA expression (Figure 6a). The $20 \mathrm{nM}$ FK228 and $16 \mu \mathrm{M}$ CBHA treatment elevated Bmf transcripts approximately 22fold and 25 -fold as assessed by real-time PCR, respectively (Figure 6b). Treatment with 10 nM FK228 strongly increased Bmf protein levels at $12 \mathrm{~h}$-incubation and knockdown of the Bmf expression strongly reduced the increase (Figure 6c) and blocked both FK228 and CBHA-induced cell death (Figure 6d), annexin $\mathrm{V}$ expression (Figure 6e) and loss of $\Delta \Psi \mathrm{m}$ (Figure 6f). Thus, distinct involvement of Bmf in FK228induced apoptosis was observed in these two independent cells. These concurring data strongly support our idea that
Bmf induction is crucial to apoptosis induced by HDAC inhibitors.

\section{FK228 activates transcription of the Bmf reporter gene}

To explore the molecular mechanism for HDAC inhibitormediated Bmf transcription activation, we isolated a $1.4 \mathrm{~kb}$ fragment upstream of the human Bmf gene from SAS genomic DNA. Using a Proscan program (version 1.7), we identified multiple AP-2, cAMP-response element (CRE) and SP1 consensus sites within the fragment (Figure 7a). The $1.4 \mathrm{~kb}$ fragment was subcloned into a reporter GL2 plasmid 
a
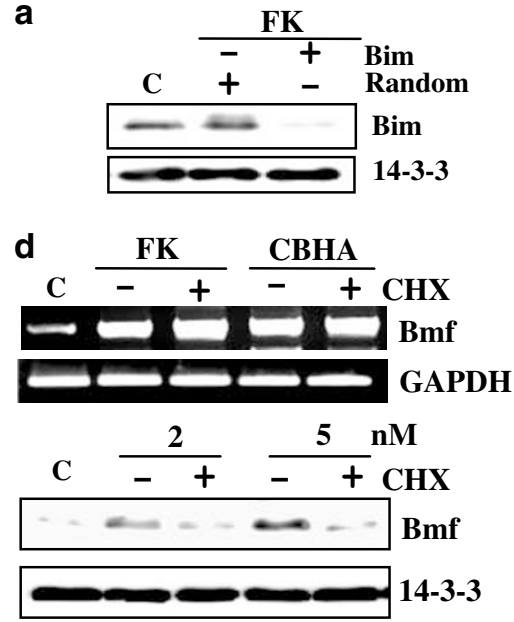

b

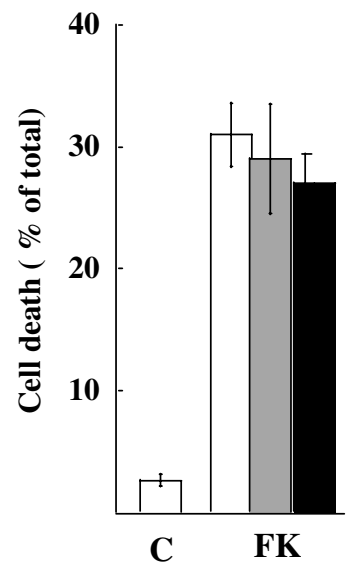

C

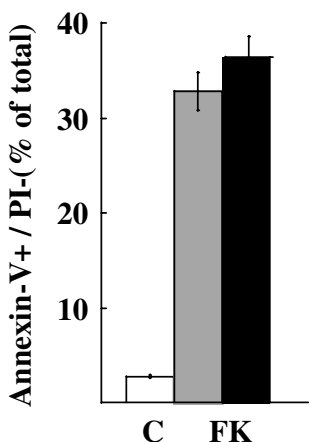

e
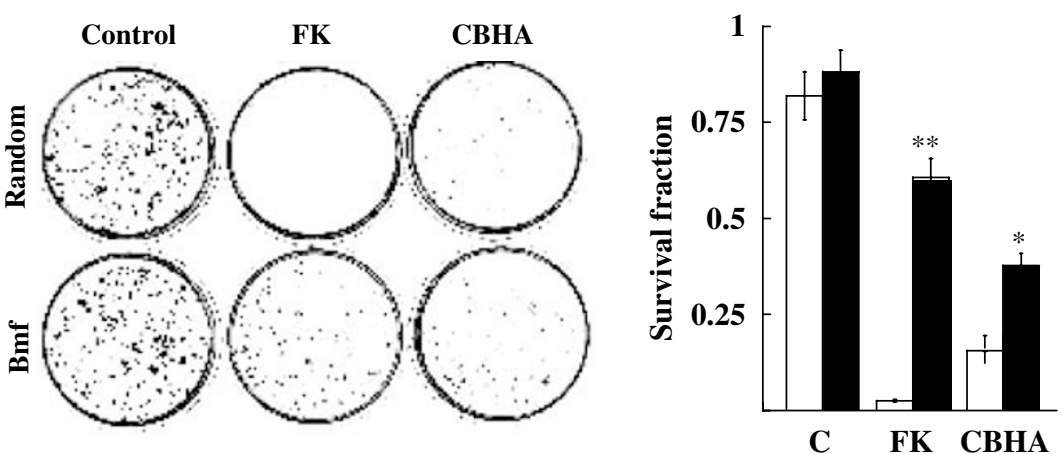

Figure 5 Effect of Bim knockdown on FK228-induced apoptosis. (a) Western blots. Cells were incubated with or without $10 \mathrm{nM}$ FK228 for $12 \mathrm{~h}$ after transfection with siRandom or siBim. The blot was probed with the anti-Bim or anti-14-3-3 antibody. (b) Trypan blue exclusion assay. Cells were transfected with the siRNA duplexes (mock, open; siRandom, gray; siBim, closed bars), thereafter treated with $10 \mathrm{nM}$ FK228 for $36 \mathrm{~h}$ and cell death was evaluated. (c) Annexin V expression assay. Annexin $V$ expression in cells transfected as described in (b), at $24 \mathrm{~h}$ after $10 \mathrm{nM} \mathrm{FK228} \mathrm{treatment.} \mathrm{(d)} \mathrm{Effect} \mathrm{of} \mathrm{CHX} \mathrm{on} \mathrm{Bmf} \mathrm{induction.} \mathrm{RT-PCR} \mathrm{was} \mathrm{performed} \mathrm{using} \mathrm{total} \mathrm{RNAs}$ from cells treated with $10 \mathrm{nM}$ FK228 or $4 \mu \mathrm{M}$ CBHA for $12 \mathrm{~h}$ in the presence $(+)$ or absence $(-)$ of $10 \mu \mathrm{g} / \mathrm{ml} \mathrm{CHX}$ (upper panel). Bmf protein expression in cells treated with 2 or $5 \mathrm{nM} \mathrm{FK228} \mathrm{for} 12 \mathrm{~h}$ in the presence or absence of $10 \mu \mathrm{g} / \mathrm{ml} \mathrm{CHX} \mathrm{(lower} \mathrm{panel).} \mathrm{(e)} \mathrm{Colony} \mathrm{assay.} \mathrm{Cells} \mathrm{were} \mathrm{transfected} \mathrm{twice} \mathrm{with} \mathrm{siRandom} \mathrm{(open)} \mathrm{or} \mathrm{siBmf}$ (closed column), transfered to new culture dishes (3000 cells/dish), and cultured in the presence or absence of $0.5 \mathrm{nM}$ FK228 or $1 \mu \mathrm{M}$ CBHA for 8 days. Colony numbers ( $>25$ cells) were counted. Representative results are shown. ${ }^{\star} P<0.05,{ }^{* \star} P<0.01$ compared with siRandom transfected cells. Columns (b, c, and $\left.\mathbf{e}\right)$ display the mean \pm S.D. of data from three separate experiments

(pGL2-Bmf) and transfected it into SAS cells. Following $4 \mathrm{~h}$ incubation after transfection, $2 \mathrm{nM}$ FK228 treatment for $12 \mathrm{~h}$ induced an approximately 14-fold increase in Bmf-Luc expression in this assay (Figure 7b). Importantly, its cotransfection with the HA-HDAC1 expression vector strongly inhibited the increase of Bmf promoter activity in a dosedependent manner (Figure 7b). Furthermore, overexpression of HDAC1 distinctly reduced expression level of intrinsic $\mathrm{Bmf}$ mRNA and its product in SAS cells (Figure 7c and d). This indicates that HDAC1 can negatively regulate Bmf transcription, thereby implying its regulation by balance of histone acetylation and deacetylation.

\section{FK228 acetylates histones associated with the Bmf gene}

Based on the foregoing data, FK228 probably activates Bmf transcripts by histone acetylation of its promoter region. To explore this idea, we employed a chromatin immunoprecipitation (ChIP) assay. As described above (Figure 2a), following
$1 \mathrm{~h}$ treatment with $20 \mathrm{nM}$ FK228, SAS cells exhibited distinct acetylation of histone $\mathrm{H} 4$. We thus evaluated histone acetylation levels at the Bmf promoter and $3^{\prime}$ regions in the treated cells (Figure 8a). The ChIP assay revealed that $10 \mathrm{nM}$ FK228 treatment increased the acetylation level of $\mathrm{H} 3$ and $\mathrm{H} 4$ at the $\mathrm{Bmf}$ promoter region, but not at its $3^{\prime}$ region or at the GAPDH gene (Figure 8b). Thus, FK228 preferentially increased acetylation of $\mathrm{H} 3$ and $\mathrm{H} 4$ at the promoter region of the Bmf gene. Similarly, FK228 induced acetylation of histones $\mathrm{H} 3$ and $\mathrm{H} 4$ selectively at the promoter region of the Bmf gene in DLD-1 cells. These data indicate that histone acetylation activates Bmf transcription and might explain why FK228 preferentially increases Bmf mRNA expression in these cells.

\section{Discussion}

We studied the molecular mechanism, by which the HDAC inhibitors (FK228 and CBHA) induce apoptosis. Although these HDAC inhibitors strongly induce cell death in a variety 
a

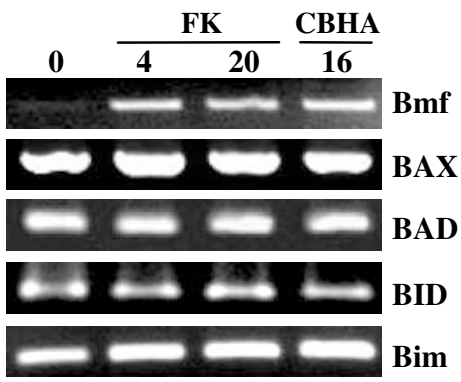

$\mathbf{C}$

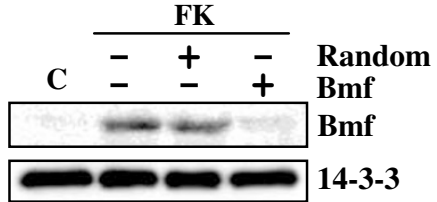

b

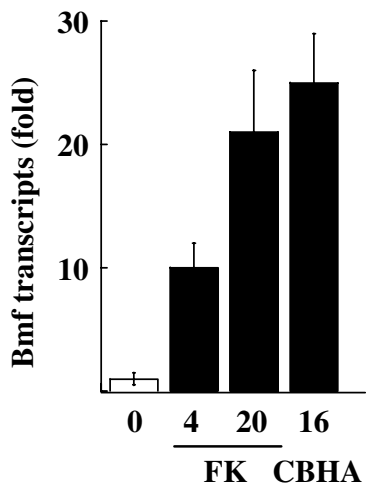

d

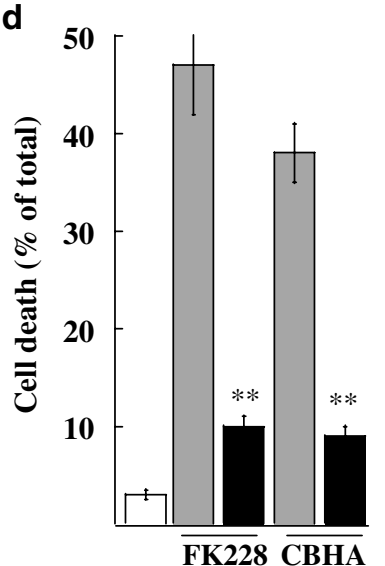

e

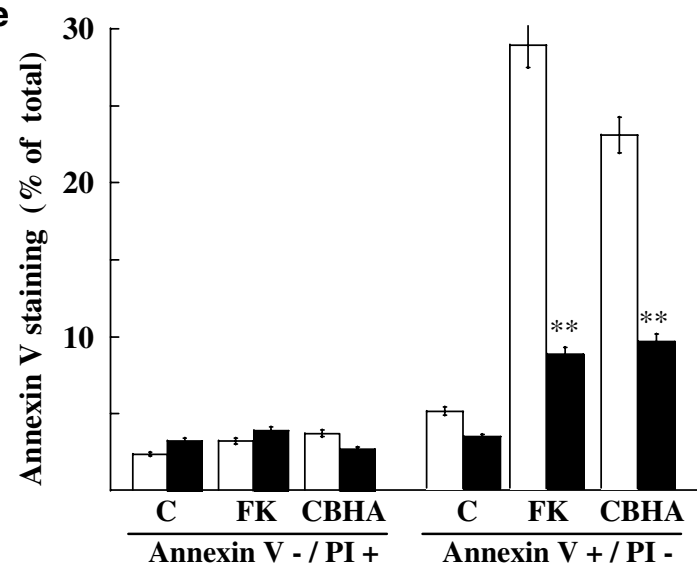

f
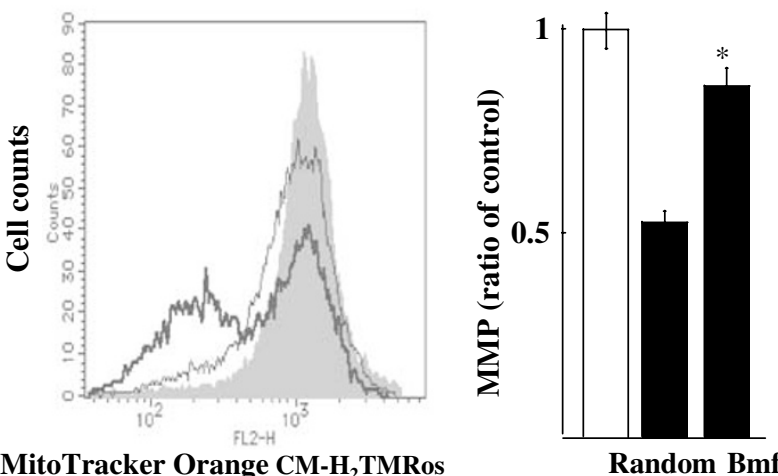

Figure 6 FK228 and CBHA similarly increased Bmf transcripts and augmented apoptosis in HSC2 cells. (a) RT-PCR. Cells were harvested $24 \mathrm{~h}$ after indicated treatment (FK, 4 or $20 \mathrm{nM}$; CBHA $16 \mu \mathrm{M}$ ). RT-PCR was performed using the indicated primers. (b) Quantitative real-time PCR. In total RNAs described in (a), Bmf (normalized to $\beta$-actin) mRNA levels were determined by real-time PCR. (c) Western blots. Cells were transfected with the siRandom (random) or siBmf (Bmf) and harvested $24 \mathrm{~h}$ after $10 \mathrm{nM}$ FK228 treatment. The blot was probed with anti-Bmf antibody or 14-3-3 antibody. (d) Trypan blue exclusion assay. Cells were transfected with the siRNA duplexes (siRandom, gray; siBmf, closed bars) and thereafter treated as indicated (FK, $10 \mathrm{nM}$ FK228; CBHA, $8 \mu \mathrm{M}$ CBHA) for $24 \mathrm{~h}$. (e) Annexin V expression. Cells were transfected with the siRandom (open) or siBmf (closed), then treated with $10 \mathrm{nM}$ FK228 or $4 \mu \mathrm{M} \mathrm{CBHA}$ for $24 \mathrm{~h}$ and annexin V expression was evaluated. (f) Disruption of $\Delta \Psi \mathrm{m}$. Cells were treated with $10 \mathrm{nM}$ FK228 for $24 \mathrm{~h}$ after transfection with siRandom (thick) or siBmf (thin), loaded with MitoTracker Orange $\mathrm{CM}-\mathrm{H}_{2} \mathrm{TMRos}$ and then its intracellular fluorescence was detected. Data of untreated cells are also shown (gray). Loss of $\Delta \Psi \mathrm{m}$ is shown by a graph plotted by calculating the mean fluorescence intensity (right panel). Columns (b, d, e, f) display the mean \pm S.D. of data from three separate experiments. ${ }^{*} P<0.05,{ }^{* *} P<0.01$ compared with siRandom transfected cells

of cancer cells, the precise mechanism(s) remains uncertain. We now clearly show that FK228 induced Bim mRNA expression in several adenocarcinoma cells, including DLD-1, BM314, COLO201 and A549 cells, but not in other cancer cell types. Importantly, a family member of Bim, Bmf was strongly induced by FK228 or CBHA in all cancer cells examined. Thus, Bmf induction appears to be much more general than Bim induction. Notably, FK228 or CBHA strongly 

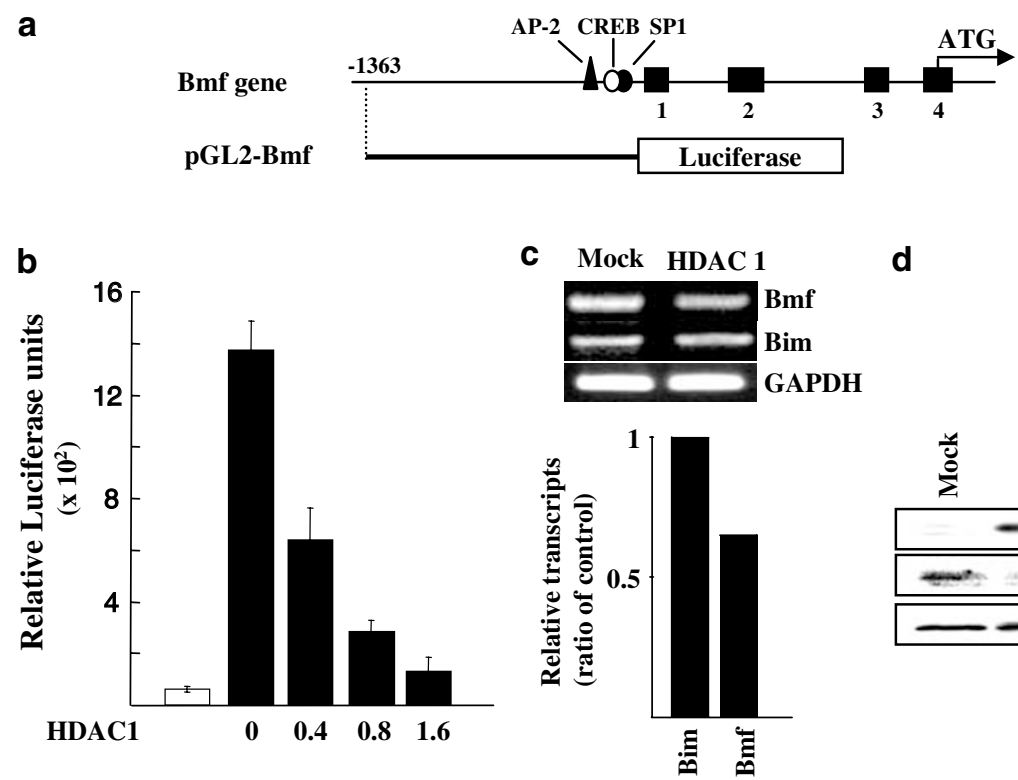

d

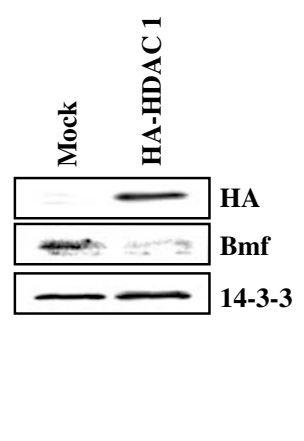

Figure 7 FK228 activates Bmf transcription. (a) Schematic representation of human Bmf promoter region and construct of pGL-Bmf reporter. Putative AP-2, CREB and SP1-like sites are shown. The number $(-1363)$ is referred to the region of the genomic fragment inserted into the pGL2Basic vector relative to the putative transcription initiation site $(+1)$ and exon (closed square) numbers were determined based on the comparing sequences of the cDNA clone BC070043 and the genomic BAC clone AC021755. (b) Inhibitory effect of HDAC1 transfection on FK228-mediated Bmf transcriptional activation. SAS cells were transfected with pGL-Bmf reporter $(0.2 \mu \mathrm{g})$ and indicated DNA amounts $\left(\mu \mathrm{g} / 5 \times 10^{4}\right.$ cells) of pCMV HA-HDAC1 or its vehicle and incubated with $2 \mathrm{nM}$ FK228 for $12 \mathrm{~h}$. Luciferase activity, normalized by Renilla luciferase activity, was measured. All columns display the mean \pm S.D. of data from three separate experiments. (c) Inhibitory effect of HDAC1 overexpression on Bmf transcripts. Cells were transfected with HA-HDAC1 or its vehicle (mock) and total RNAs were harvested $36 \mathrm{~h}$ after transfection to evaluate expression of Bmf or Bim transcripts (normalized to GAPDH transcripts). (d) Inhibitory effect of HDAC1 on Bmf. Total cell lysates were harvested from cells described in (c). The blots were probed with anti-Bmf, anti-HA antibody or 14-3-3 antibody

induced Bmf expression, but not Bim, in squamous carcinoma SAS and HSC-2 cells, suggesting a more important role of Bmf.

Most importantly, knockdown of Bmf expression profoundly inhibited proapoptotic action of FK228 in both SAS and HSC2 cells. However, knockdown of Bim expression only slightly inhibited the FK228-induced death in SAS cells. This suggests that an involvement of Bim is marginal for FK228induced apoptosis, although we could not simply evaluate or compare their roles by these transfection experiments alone. Furthermore, we found that FK228 and CBHA, but not cisplatin, induced Bmf expression. In parallel, siRNAmediated knockdown of Bmf transcripts did not inhibit cisplatin-induced cell death. Thus, we strongly suggest that Bmf induction is the crucial event in HDAC inhibitor-mediated apoptosis. Several findings support our proposal. First, siRNA mediated suppression of Bmf expression almost completely prevented FK228-mediated cell death. Second, Bim siRNA transfection only slightly reduced FK228-mediated proapoptotic activity. Third, gene transfer-mediated overexpression of Bmf alone readily induced cell death in SAS cells. Fourth, Bmf induction was the most consistent observation in a broad array of cancer cell lines. Fifth, the kinetics of Bmf induction showed that an increase of Bmf mRNA and its product was apparent $12 \mathrm{~h}$ after $5 \mathrm{nM}$ FK228 treatment, and this preceded the appearance of distinct apoptotic features.

A number of reports originally suggested that several HDAC inhibitors did not modulate apoptosis-related molecules significantly. Indeed, some researchers employed gene expression profiling of HDAC inhibitors but failed to identify upregulated proapoptotic genes. ${ }^{26,27}$ However, a recent report indicates that an HDAC inhibitor, trichostatin $A$, increases the ratio between the levels of expression of proapoptotic (Bim) and anti-apoptotic (Bcl-XL and $\mathrm{Bcl}-\mathrm{W}) .{ }^{28}$ We, and others, also showed that FK228 increases a proapoptotic BH3-only protein Bim in MKN45 and DLD-1 cells, ${ }^{23}$ and inhibits expression of the anti-apoptotic molecules, Bcl-2, $\mathrm{Bcl}-\mathrm{XL}$ and $\mathrm{MCl}-1 .{ }^{29} \mathrm{FK} 228$ also decreases expression of FLICE inhibitory protein (FLIP) in osteosarcoma and leukemic cells. ${ }^{21,30}$ Thus, expression of many apoptosis-related molecules could be modified by HDAC inhibitors. However, we found that FK228 treatment did not change Bcl-2 and Bcl-XL expression and barely affected expression of Bid, Bad, Bim and BAX in SAS and HSC2 cells, suggesting their marginal contribution in FK228 or CBHA-induced apoptosis, though we cannot exclude the possibility that they are somehow involved in the event.

To explore the molecular mechanism(s) by which FK228 augments Bmf expression, we isolated a genomic DNA fragment containing the promoter region of human Bmf gene. Computer-assisted sequence analysis revealed that the human Bmf promoter region contains a CpG island but lacks an identifiable TATA element and initiator sequence. This genomic DNA showed strong transcriptional activation, comparable to that of GRE-mediated activation in response to FK228 (data not shown), suggesting that this region may be highly regulated by histone acetylation level. Consistent with this idea, the promoter region of the Bmf gene possesses 
Primers for promoter region

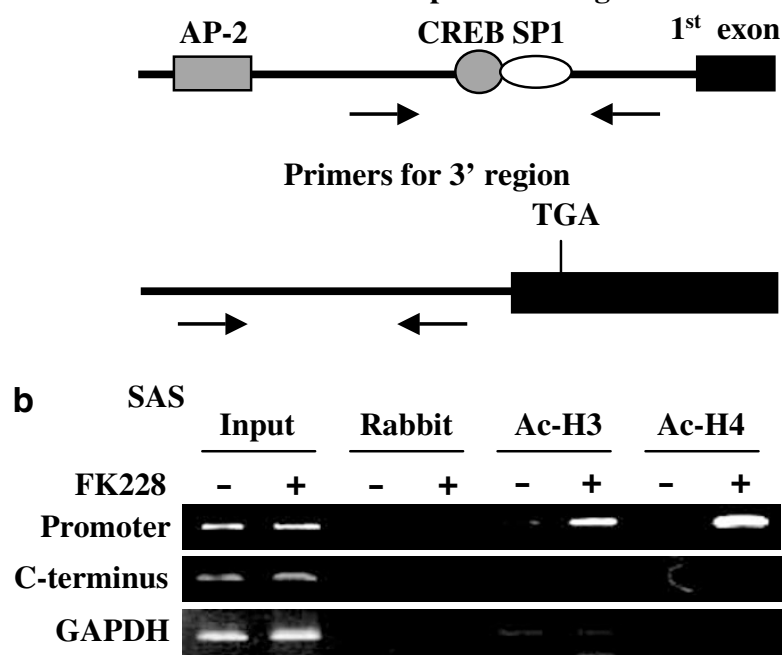

DLD-1

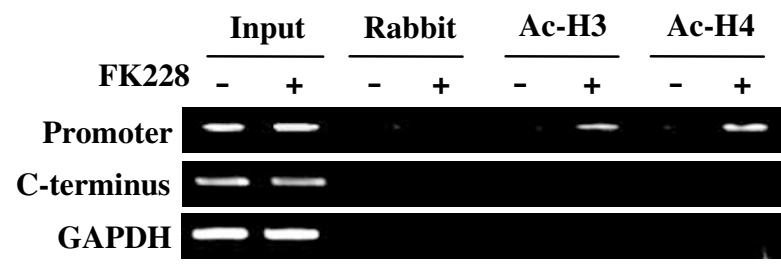

Figure 8 Histone acetylation status of Bmf promoter. (a) Schematic representation of Bmf gene and the primer design for ChIP assay. (b) A ChIP experiment using SAS (upper panel) or DLD-1 (lower panel) cells treated with $(+)$ or without $(-) 10 \mathrm{nM}$ FK228 for $0.5 \mathrm{~h}$. Antibodies against histone $\mathrm{H3}$ acetylated, histone $\mathrm{H} 4$-acetylated, or nonimmunized rabbit serum were used for immunoprecipitation. A fixed portion of the total input was also examined by PCR The promoter region of Bmf was amplified by corresponding primers, and its $3^{\prime}$ region and GAPDH gene were also amplified as control studies

multiple potential HAT-regulating promoters including consensus AP2-like (CCCAGCCCGGG), CREB-like (TGCGCGTCA) and $\mathrm{Sp} 1$ sequences $\left(5^{\prime}-\mathrm{GGGGGCGGGGC-3}\right) \cdot{ }^{31-33}$ Like most promoter activities, this may reflect the fact that FK228mediated Bmf transcription can be activated depending upon these multiple promoter activities. This may at least partially explain why FK228 or CBHA activates Bmf expression differently in different cells, since these promoter activity may differ depending upon cell types.

We have shown that FK228 and CBHA activate Bmf transcription, and this activation may be through histone hyperacetylation. However, it may not always be true, since we, and others, previously found that several HDAC inhibitors may affect intracellular signals other than histone hyperacetylation. ${ }^{25}$ We here found that FK228 selectively increased acetylation of histones $\mathrm{H} 3$ and $\mathrm{H} 4$ at the promoter region of the Bmf gene. In addition, overexpression of HDAC1 strongly inhibited FK228-induced Bmf expression. Thus, hyperacetylation of histones is probably necessary for activation of Bmf transcription. However, we still do not exclude the possibility that hyperacetylation of transcription factors is also involved in the process. Disregarding the precise molecular mechanism, our data are the first to shed the light on the linkage between Bmf transcriptional activation and acetylation.
Our current study suggests that Bmf expression is increased by hyperacetylation, and its induction is crucial for HDAC inhibitor-mediated cell death. Although several reports describe an altered Bmf expression during differentiation of neurons and different expression patterns of Bmf isoforms in malignant lymphoid cells, ${ }^{34,35}$ Bmf functions are believed to be mainly regulated by phosphorylation. Namely, Bmf is phosphorylated and sequestered from interaction with dynein light chain 2 (DLC2), a component of the myosin $\mathrm{V}$ motor complex upon activation of JNK stress MAP kinase. ${ }^{24,36}$ In this context, our data may represent an additional mechanism that accounts for Bmf activation.

\section{Materials and Methods}

\section{Cell cultures}

Human squamous SAS, HSC-2, T Tn, embryonal 293, colorectal DLD-1, BM314 and COLO201, pulmonary A549, acute T-cell leukemia Jurkat, myeloma KSM-12-PE, glioma U-251MG and A172 carcinoma cells, obtained from the Japanese Cancer Research Resources Bank (Tokyo, Japan), were grown in RPMI1640, d-MEM or essential MEM supplemented with $10 \%$ fetal calf serum (FCS). To evaluate viability, cells were mixed with the same volume of $0.4 \%$ trypan blue solution, and immediately examined to determine whether they excluded the dye under light microscopical observation.

\section{DAPI staining}

Cells were seeded in six-well plates at a density of $3 \times 10^{5}$ cells/well, and cultured with the indicated treatment. After fixation in $70 \%$ ethanol for $10 \mathrm{~min}$, cells were stained with DAPI $(0.5 \mu \mathrm{g} / \mathrm{ml} \mathrm{PBS})$ for $10 \mathrm{~min}$ and chromatin fluorescence was observed under UV-light using a confocal microscope (R2100AG2, BIORAD).

\section{Reagents and expression constructs}

HDAC inhibitors bicyclic depsipeptide (FK228) and CBHA were kindly provided by Fujisawa Pharmaceutical Co. (Osaka, Japan), and obtained from Calbiochem-Novabiochem Co. (Darmstadt, Germany), respectively. Cisplatin was kindly provided by Nippon Kayaku Co. (Tokyo, Japan). 5Fluorouracil (5-FU) and cycloheximide (CHX) were from Sigma (St. Louis, MO). HDAC1 expression vector, pCMV HA-HDAC1, was kindly provided from Dr. Harel-Bellan A (CNRS, France).

\section{Antibodies}

The anti-Bmf antibodies were purchased from ProSci Co. (Poway, CA, USA) and Alexis (San Diego, CA, USA). The anti-14-3-3, anti-BAX, anti$\mathrm{Bcl}-2$ and anti-Bim antibodies were from Santa Cruz Biotechnology Inc. (Santa Cruz, CA, USA). The anti-BAD and anti-Bcl-xL antibody was from Cell Signaling Technology (Beverly, MA, USA) and Transduction Laboratories (Lexington, KY, USA), respectively. The anti-hemagglutinin (HA) and anti-Bid antibody was from Boehringer Mannheim (Ingelheim Germany) and MBL (Nagoya, Japan), respectively.

\section{DNA fragmentation assay}

As described previously, ${ }^{37}$ low-molecular weight genomic DNA extracted with the lysis buffer $(0.5 \%$ Triton X-100, $10 \mathrm{nM}$ EDTA and $10 \mathrm{mM}$ Tris- $\mathrm{HCl}$, 
$\mathrm{pH}$ 7.4) was treated with $400 \mu \mathrm{g} / \mathrm{ml}$ of RNase A and Proteinase $\mathrm{K}$ for $1 \mathrm{hr}$ at $37^{\circ} \mathrm{C}$, isopropanol precipitated and subjected onto $1 \%$ agarose gels. The gels were stained with $1 \mu \mathrm{g} / \mathrm{ml}$ of ethidium bromide.

\section{Detection of $\Delta \Psi \mathrm{m}$}

Following treatment, cells were incubated with $0.5 \mu \mathrm{M}$ MitoTracker Orange $\mathrm{CM}-\mathrm{H}_{2}$ TMRos (Molecular Probes) for $30 \mathrm{~min}$, after which they were washed with PBS, $\triangle \Psi \mathrm{m}$ was determined using a FACScan flow cytometer (Becton Dickinson, Mountain View, CA, USA). MitoTracker Orange $\mathrm{CM}-\mathrm{H}_{2}$ TMRos does not fluoresce until it enters an actively respiring cell, where they are oxidized to fluorescent mitochondronselective probes, and the fluorescent signals (FL2) were displayed as histograms or graphs by calculating the mean fluorescence intensity.

\section{Annexin $\mathbf{V}$ binding analysis}

Cells $\left(1 \times 10^{6}\right)$ were incubated with green fluorescent protein (GFP)annexin $\mathrm{V}$ for $20 \mathrm{~min}$, washed, further incubated with propidium iodide (PI) for $5 \mathrm{~min}$ following the manufacturer's protocol (MBL), and analyzed for cellular fluorescence by FACScan flow cytometry (Becton Dickinson, Mountain View, CA, USA) using CellQuest Software ${ }^{\mathrm{TM}}$.

\section{Colony assay}

Cells $\left(3 \times 10^{3}\right)$ were seeded on to $60 \mathrm{~mm}$-plates and cultured with the indicated treatment for 8 days and the number of colonies ( $>25$ cells) was counted. Survival fraction was defined as number of colonies divided by the number of plated cells.

\section{Western blotting}

After washing with ice-cold PBS, cells were lyzed by adding $200 \mu \mathrm{l}$ of RIP A buffer (100 mM NaCl, 2 mM EDTA, $1 \mathrm{mM} \mathrm{PMSF,} \mathrm{1 \%} \mathrm{NP-40} \mathrm{and} 50 \mathrm{mM}$ Tris- $\mathrm{HCl}(\mathrm{pH} 7.2))$. The lysates $(20 \mu \mathrm{g} /$ lane) were separated by $10-15 \%$ SDS-PAGE gels and then transferred to PVDF membranes (Millipore, Bedford, MA). Membranes were soaked in $5 \%$ bovine serum albumin (BSA, Sigma) and incubated with primary antibodies overnight at $4{ }^{\circ} \mathrm{C}$, and thereafter incubated with the corresponding peroxidase-linked secondary antibodies (Amersham or MBL) for $1 \mathrm{~h}$ at room temperature. Signals were developed by a standard enhanced chemiluminescence (ECL) method following the manufacturer's protocol (Amersham).

\section{Reverse transcriptase-PCR and transfection}

Total RNA of SAS or HCS-2 cells was extracted with TRIzol (BRL Life and Technologies, MD, USA). The indicated cDNAs were amplified from $2 \mu \mathrm{g}$ of total RNA using M-MLV Reverse transcriptase (Invitrogen, Carlsbad, CA, USA) with oligo (dT) 12-18 and the Platinum Quantitative RT-PCR ThermoScript One-Step System (Life Technologies), and cloned using the TOPO TA Cloning Kit (Invitrogen). The cDNA products were analyzed on $2 \%$ agarose gel and confirmed by nucleotide sequencing. The following primer pairs were used for RT-PCR: Bmf: $5^{\prime}$-atggagccatctcagtgtgtg- $3^{\prime}$ and $5^{\prime}$-ccccgttcctgttctcttct-3'; GAPDH: $5^{\prime}$-cgaccactttgtcaagctca- $3^{\prime}$ and $5^{\prime}$ aggggtctacatggcaactg- $3^{\prime}$; Bim: $5^{\prime}$-ctgcagatatgcgcccagagat- $3^{\prime}$ and $5^{\prime}$ caccaggcggacaatgtaacg- $3^{\prime}$; Bid: $5^{\prime}$-gcatgtcaacagcgttccta- $3^{\prime}$ and $5^{\prime}$ ggaacctgcacagtggaaat- $3^{\prime}$; Bad: $5^{\prime}$-gcggatccgccaccatgttccagatcccagag- $3^{\prime}$ and $5^{\prime}$-gcggatccgctcactgggagggggcggagcttc-3'; BAX: 5'-ggaactgatca gaaccatca- $3^{\prime}$ and $5^{\prime}$-tcagcccatcttcttccaga- $3^{\prime}$. Specificity of amplified PCR fragments were confirmed by DNA sequence analysis. An isolated full-length human Bmf clone was sequenced and subcloned into a GFP expression vector pEGFP (Clontech, CA, USA). The pEGFP-Bmf $(3 \mu \mathrm{g} /$ $10 \mathrm{~cm}^{2}$ ) or its vehicle was transfected using LipofectAMINE 2000 (Life and Technologies, MD, USA). The efficiency of transfection was achieved at $30-50 \%$ for both cells. At $4-12 \mathrm{~h}$ after transfection, cells were treated as indicated and harvested to evaluate their apoptotic state.

\section{Quantitative PCR}

Quantitative PCR was carried out using an ABI Prism 7000 sequence detection system with standard temperature protocol and $2 \times$ QuantiTect SYBR Green PCR Master Mix reagent (Qiagen) in $25 \mu \mathrm{l}$ volume, in triplicates. $300 \mathrm{nM}$ concentrations of the following primer pairs were used for the reactions: Bmf: forward, $5^{\prime}$-ccaccagccaggaagacaaag-3'; reverse, $5^{\prime}$-tgctccccaatgggcaagact- $3^{\prime}$ and human $\beta$-actin: forward, $5^{\prime}$ gctcctcctgagcgcaagt- $3^{\prime}$; reverse $5^{\prime}$-tcgtcatactcctgcttgctgat- $3^{\prime}$. All amplifications were carried out in MicroAmp optical 96-well reaction plates with optical adhesive covers (Applied Biosystems). The accumulation of PCR products was detected by monitoring the increase in fluorescence of the reporter dye.

\section{Small RNA interference}

The 21-nt duplex siRNAs for Bmf (target sequence of $5^{\prime}$-aaaggtgtcatgctgccttgt- $3^{\prime}$ ), Bim (target sequence of $5^{\prime}$-gaccgagaaggtagacaattg- $3^{\prime}$ ), and control siRNAs (random; 5'-NNACTCTATCTGCACGCTGAC-3') were synthesized by Dharmacon. Cells were plated at $0.5 \times 10^{5}$ cells per well in a 24-well plate, incubated for $24 \mathrm{~h}$, and transfected either with Bmf or Bim siRNA (siBmf, siBim) or control random siRNA (siRandom) duplexes (100 nmol each) using LipofectAMINE 2000 according to the manufacturer's instructions.

\section{Luciferase assay}

SAS cells were seeded in 24-well plates at a density of $5 \times 10^{4}$ cells/well and transfected with LipofectAMINE 2000. Luciferase assays were carried out according to the manufacturer's protocol with Dual Luciferase assay kit (Promega), and luciferase activity was quantified by using Wallac 1420 multilabel counter (PerkinElmer Life Sciences) as descrived previously. ${ }^{38}$ A 1341-bp fragment corresponding to nucleotides -1364 to -23 of the human Bmf promoter (tentative) was amplified by PCR from SAS genomic DNA using the primers, $5^{\prime}$-taagctctccagctcagcac- $3^{\prime}$ and $5^{\prime}$-atcccgcaaacagctgat-3' and cloned into pGL2 basic luciferase reporter vector (Promega) to generate pGL2-Bmf. Determination of the first exon was performed on the basis of a matching process between cDNA (Accession number $\mathrm{BC070043)}$ and the genomic sequences according to the BAC clone (Accession number AC021755).

\section{ChIP analysis}

The ChIP assay was performed using a ChIP assay kit (UBI) according to the manufacture's protocol. After incubation with $10 \mathrm{nM}$ FK228, SAS cells were fixed with formaldehyde for $10 \mathrm{~min}$. Chromatin was sonicated to an average length of $0.2-2 \mathrm{~kb}$. The chromatin complex was immunoprecipitated using anti-acetylated histone $\mathrm{H} 4$, anti-acetylated histone $\mathrm{H} 3$ or control rabbit lgG. PCR amplification was performed in $25 \mu \mathrm{l}$ with specific primers for each of the analyzed promotors, primers for Bmf promoter, $5^{\prime}$ ttggcgcttcactcgccatt- $3^{\prime}$ and $5^{\prime}$-atcccgcaaacagctgat- $3^{\prime}$; for its $3^{\prime}$ region, $5^{\prime}$ aagagacactgccatgtgga- $3^{\prime}$ and $5^{\prime}$-tgaagccagtttgttgttca-3'; for GAPDH, $5^{\prime}$ gggctccttctgctgat- $3^{\prime}$ and $5^{\prime}$-gggctgggtggcagtgat- $3^{\prime}$. For each promoter, the 
sensitivity of PCR amplification was evaluated on total DNA collected after sonication (input fraction). Three independent experiments were performed and similar results were obtained.

\section{Acknowledgements}

We thank Dr P Olley (Sapporo medical University) for critical reading of the manuscript. This work was supported in part by Grants-in-Aid for Scientific Research from the Ministry of Education, Culture, Sports, Science, and Technology of Japan, and grants from Cancer Research Foundation (JJCO).

\section{References}

1. Kouzarides $T$ (2000) Acetylation: a regulatory modification to rival phosphorylation? EMBO J. 19: 1176-1179

2. Yoshida M and Horinouchi S (1999) Trichostatin and leptomycin. Inhibition of histone deacetylation and signal-dependent nuclear export. Ann. NY. Acad. Sci. 886: 23-36

3. Marks PA, Richon VM and Rifkind RA (2000) Histone deacetylase inhibitors: inducers of differentiation or apoptosis of transformed cells. J. Natl. Cancer Inst. 92: $1210-1216$

4. Nervi C, Borello U, Fazi F, Buffa V, Pelicci PG and Cossu G (2001) Inhibition of histone deacetylase activity by trichostatin A modulates gene expression during mouse embryogenesis without apparent toxicity. Cancer Res. 61: 1247-1249

5. Goldsmith ME, Kitazono M, Fok P, Aikou T, Bates S and Fojo T (2003) The histone deacetylase inhibitor FK228 preferentially enhances adenovirus transgene expression in malignant cells. Clin. Cancer Res. 9: 5394-5401

6. Peart MJ, Tainton KM, Ruefli AA, Dear AE, Sedelies KA, O'Reilly LA, Waterhouse NJ, Trapani JA and Johnstone RW (2003) Novel mechanisms of apoptosis induced by histone deacetylase inhibitors. Cancer Res. 63: 4460 4471

7. Vigushin DM and Coombes RC (2002) Histone deacetylase inhibitors in cancer treatment. Anticancer Drugs 13: 1-13

8. Furumai $R$, Matsuyama $A$, Kobashi $N$, Lee $K H$, Nishiyama M, Nakajima $H$, Tanaka A, Komatsu Y, Nishino N, Yoshida M and Horinouchi S (2002) FK228 (depsipeptide) as a natural prodrug that inhibits class I histone deacetylases. Cancer Res. 62: 4916-4921

9. Sandor V, Bakke S, Robey RW, Kang MH, Blagosklonny MV, Bender J, Brooks R, Piekarz RL, Tucker E, Figg WD, Chan KK, Goldspiel B, Fojo AT, Balcerzak SP and Bates SE (2002) Phase I trial of the histone deacetylase inhibitor, depsipeptide (FR901228, NSC 630176), in patients with refractory neoplasms. Clin. Cancer Res. 8: 718-728

10. Piekarz RL, Robey RW, Zhan Z, Kayastha G, Sayah A, Abdeldaim AH, Torrico $S$ and Bates SE (2004) T-cell lymphoma as a model for the use of histone deacetylase inhibitors in cancer therapy: impact of depsipeptide on molecular markers, therapeutic targets, and mechanisms of resistance. Blood 103: 46364643

11. Richon VM, Webb Y, Merger R, Sheppard T, Jursic B, Ngo L, Civoli F, Breslow R, Rifkind RA and Marks PA (1996) Second generation hybrid polar compounds are potent inducers of transformed cell differentiation. Proc. Natl. Acad. Sci. USA 93: 5705-5708

12. Glick RD, Swendeman SL, Coffey DC, Rifkind RA, Marks PA, Richon VM and La Quaglia MP (1999) Hybrid polar histone deacetylase inhibitor induces apoptosis and CD95/CD95 ligand expression in human neuroblastoma. Cancer Res. 59: 4392-4399

13. Coffey DC, Kutko MC, Glick RD, Butler LM, Heller G, Rifkind RA, Marks PA, Richon VM and La Quaglia MP (2001) The histone deacetylase inhibitor, $\mathrm{CBHA}$, inhibits growth of human neuroblastoma xenografts in vivo, alone and synergistically with all-trans retinoic acid. Cancer Res. 61: 3591-3594

14. Richon VM, Sandhoff TW, Rifkind RA and Marks PA (2000) Histone deacetylase inhibitor selectively induces p21WAF1 expression and geneassociated histone acetylation. Proc. Natl. Acad. Sci. USA 97: 10014-10019

15. Han JW, Ahn SH, Park SH, Wang SY, Bae GU, Seo DW, Kwon HK, Hong S Lee HY, Lee YW and Lee HW (2000) Apicidin, a histone deacetylase inhibitor, inhibits proliferation of tumor cells via induction of p21WAF1/Cip1 and gelsolin. Cancer Res. 60: 6068-6074

16. Ju R and Muller MT (2003) Histone deacetylase inhibitors activate p21(WAF1) expression via ATM. Cancer Res. 63: 2891-2897

17. Kim JH, Choi YK, Kwon HJ, Yang HK, Choi JH and Kim DY (2004) Downregulation of gelsolin and retinoic acid receptor beta expression in gastric cancer tissues through histone deacetylase 1. J. Gastroenterol. Hepatol. 19: 218-224

18. Nakata S, Yoshida T, Horinaka M, Shiraishi T, Wakada M and Sakai T (2004) Histone deacetylase inhibitors upregulate death receptor 5/TRAIL-R2 and sensitize apoptosis induced by TRAIL/APO2-L in human malignant tumor cells. Oncogene 23: 6261-6271

19. $\mathrm{Yu}$ X, Guo ZS, Marcu MG, Neckers L, Nguyen DM, Chen GA and Schrump DS (2002) Modulation of p53, ErbB1, ErbB2, and Raf-1 expression in lung cancer cells by depsipeptide FR901228. J. Natl. Cancer Inst. 94: 504-513

20. Nimmanapalli R, Fuino L, Bali P, Gasparetto M, Glozak M, Tao J, Moscinski L, Smith C, Wu J, Jove R, Atadja P and Bhalla K (2003) Histone deacetylase inhibitor LAQ824 both lowers expression and promotes proteasomal degradation of Bcr-Abl and induces apoptosis of imatinib mesylate-sensitive or -refractory chronic myelogenous leukemia-blast crisis cells. Cancer Res. 63 : 5126-5135

21. Watanabe K, Okamoto K and Yonehara S (2005) Sensitization of osteosarcoma cells to death receptor-mediated apoptosis by HDAC inhibitors through downregulation of cellular FLIP. Cell Death Differ. 12: 10-18

22. Cohen HY, Lavu S, Bitterman KJ, Hekking B, Imahiyerobo TA, Miller C, Frye R, Ploegh $H$, Kessler BM and Sinclair DA (2004) Acetylation of the $C$ terminus of Ku70 by CBP and PCAF controls Bax-mediated apoptosis. Mol. Cell 13: 627-638

23. Zhang $Y$, Adachi $M$, Zhao $X$, Kawamura $R$ and Imai $K$ (2004) Histone deacetylase inhibitors FK228, $\mathrm{N}$-(2-aminophenyl)-4-[N-(pyridin-3-yl- methoxycarbonyl) amino- methyl] benzamide and m-carboxycinnamic acid bishydroxamide augment radiation-induced cell death in gastrointestinal adenocarcinoma cells. Int. J. Cancer 110: 301-308

24. Lei K and Davis RJ (2003) JNK phosphorylation of Bim-related members of the Bcl2 family induces Bax-dependent apoptosis. Proc. Natl. Acad. Sci. USA 100: 2432-2457

25. Koyama Y, Adachi M, Sekiya M, Takekawa M and Imai K (2002) Histone deacetylase inhibitors suppress IL-2-mediated gene expression prior to induction of apoptosis. Blood 96: 1490-1495

26. Glaser KB, Staver MJ, Waring JF, Stender J, Ulrich RG and Davidsen SK (2003) Gene expression profiling of multiple histone deacetylase (HDAC) inhibitors: defining a common gene set produced by HDAC inhibition in T24 and MDA carcinoma cell lines. Mol. Cancer Ther. 2: 151-163

27. Mitsiades N, Mitsiades CS, Richardson PG, McMullan C, Poulaki V, Fanourakis G, Schlossman R, Chauhan D, Munshi NC, Hideshima T, Richon VM, Marks $\mathrm{PA}$ and Anderson KC (2003) Molecular sequelae of histone deacetylase inhibition in human malignant B cells. Blood 101: 4055-4062

28. Moore PS, Barbi S, Donadelli M, Costanzo C, Bassi C, Palmieri M and Scarpa A (2004) Gene expression profiling after treatment with the histone deacetylase inhibitor trichostatin A reveals altered expression of both pro- and anti-apoptotic genes in pancreatic adenocarcinoma cells. Biochem. Biophys. Acta 1693: 167-176

29. Khan SB, Maududi T, Barton K, Ayers J and Alkan S (2004) Analysis of histone deacetylase inhibitor, depsipeptide (FR901228), effect on multiple myeloma. Br. J. Haematol. 125: 156-161

30. Aron JL, Parthun MR, Marcucci G, Kitada S, Mone AP, Davis ME, Shen T, Murphy T, Wickham J, Kanakry C, Lucas DM, Reed JC, Grever MR and Byrd JC (2003) Depsipeptide (FR901228) induces histone acetylation and inhibition of histone deacetylase in chronic lymphocytic leukemia cells concurrent with activation of caspase 8-mediated apoptosis and down-regulation of c-FLIP protein. Blood 102: 652-658

31. Braganca J, Eloranta JJ, Bamforth SD, Ibbitt JC, Hurst HC and Bhattacharya $S$ (2003) Physical and functional interactions among AP-2 transcription factors, p300/CREB-binding protein, and CITED2. J. Biol. Chem. 278: 16021-16029

32. Chrivia JC, Kwok RP, Lamb N, Hagiwara M, Montminy MR and Goodman RH (1993) Phosphorylated CREB binds specifically to the nuclear protein CBP. Nature 365: 855-859 
33. Owen Gl, Richer JK, Tung L, Takimoto G and Horwitz KB (1998) Progesterone regulates transcription of the p21WAF1 cyclindependent kinase inhibitor gene through Sp1 and CBP/p300. J. Biol. Chem. 273: 10696-10701

34. Itoh $\mathrm{T}$, Itoh A and Pleasure D (2003) Bcl-2-related protein family gene expression during oligodendroglial differentiation. J. Neurochem. 85 : $1500-1512$

35. Morales AA, Olsson A, Celsing F, Osterborg A, Jondal M and Osorio LM. (2004) Expression and transcriptional regulation of functionally distinct Bmf isoforms in B-chronic lymphocytic leukemia cells. Leukemia 18: 41-47
36. Puthalakath H, Villunger A, O'Reilly LA, Beaumont JG, Coultas L, Cheney RE, Huang DC and Strasser A (2001) Bmf: a proapoptotic BH3-only protein regulated by interaction with the myosin $\mathrm{V}$ actin motor complex, activated by anoikis. Science 293: 1829-1832

37. Takaoka A, Adachi M, Okuda H, Sato S, Yawata A, Hinoda Y, Takayama S, Reed JC and Imai K (1997) Anti-cell death activity promotes pulmonary metastasis of melanoma cells. Oncogene 14: 2971-2977

38. Itoh M, Adachi M, Yasui H, Takekawa M, Tanaka H and Imai K (2002) Nuclear export of glucocorticoid receptor is enhanced by c-Jun N-terminal kinasemediated phosphorylation. Mol Endocrinol. 16: 2382-2392 